\title{
A smorgasbord of tasty titles for Easter
}

\section{Compiled by Helen Nield}

To borrow any of these titles please email library@bda.org or call 0207563 4545. Although members are responsible for return postage costs, books are sent out to them free of charge. They may be kept for at least four weeks and can be renewed if not requested by others. Members can have up to ten items on loan at any one time.

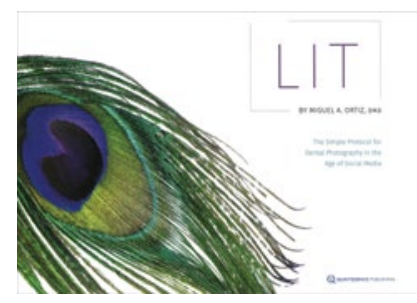

\section{LIT: THE SIMPLE PROTOCOL FOR DENTAL PHOTOGRAPHY IN THE AGE OF SOCIAL MEDIA}

Miguel A. Ortiz

2019; Quintessence Publishing; 237 pp; hardback

ISBN: 9780867158021

'LIT was born because I got addicted to my colleagues' smiles. I have simplified and demystified the art of dental photography. I start with the fundamentals. I do not attempt to teach you only how to take pictures of pretty lips and glossy teeth. I teach you how to be a photographer, to take ALL pictures. Any picture.'

This landscape style book is full of glossy images with a reasonable amount of descriptive and informative text. It is divided into eight chapters which discuss the fundamentals of photography, equipment, portrait and intraoral photography, artistic dental photography, communication with the dental laboratory, dental laboratory photography and marketing and social media. The text covers basic and advanced techniques including the artistic manipulation of images and shows how photography can be incorporated into your normal clinical workflow. The idea of the whole book is to provide you with the tools to produce good quality images to help improve your social media presence but the final chapter gives some concrete advice specifically on this subject.

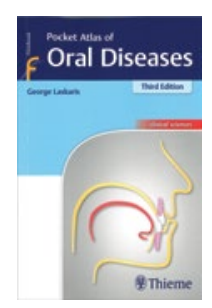

\section{POCKET ATLAS OF ORAL DISEASES (3RD EDITION)}

\section{George Laskaris}

2019; Thieme Medical Publishers; 413 pp; 418 ill; paperback

ISBN: 9783132417878

'The visual approach is the most powerful tool at the disposal of the oral physician. Acquisition of the skill to "see" lesions in a particular way requires extensive and intensive clinical training and is rewarded with a high degree of diagnostic accuracy.'
This pocket picture book is packed with photographs, the majority of which are new to this edition. Also new to this edition are 40 new diseases and an extra chapter. Each disease is given a short description comprising a definition, aetiology, clinical features, laboratory tests, differential diagnosis and treatment and is accompanied by at least one photograph. A schematic classification of oral diseases in the form of a tree opens the book which is then divided into 13 sections: White lesion; Red lesions; Black and brown lesions; Vesiculobullous lesions; Ulcerative lesions; Gingival enlargement; Soft-tissue tumors; Soft-tissue cysts; Bone swellings; Neck swellings; Lip disorders; Tongue disorders.

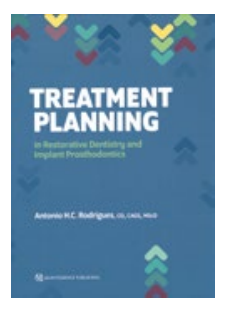

\section{TREATMENT PLANNING IN RESTORATIVE DENTISTRY AND IMPLANT PROSTHODONTICS}

Antonio H. C. Rodrigues

2020; Quintessence Publishing; 306 pp; hardback

ISBN: 9780867158267

'The frustration and looks of despair on the faces of my students and the difficulties encountered by so many dentists when faced with the necessity to solve complicated cases without having a clue as to what to do or which direction to go inspired me to write this book. In it, I present clinical guidelines for planning treatments in restorative dentistry and outline a clear, objective, and simple thinking process that can be easily applied in daily practice.'

Written for students, general practitioners and restorative dentists this book covers all aspects of treatment planning for adult patients. It begins with a philosophical chapter looking at the rationale behind a philosophy of total care which encompasses a historical overview of planning methods. After this the book is divided into three sections: Part one - the planning process: identifying existing problems; Part two - the planning process: providing solutions to identified problems; Part three - presenting treatment plans and obtaining consent to treatment. The book has not specifically been written for practitioners in the UK and there are not a lot of up to date references. However, it is a comprehensive text, readable and very clearly set out with useful charts and images as well as a section on 'Forms for recording and organising examination data'. 
endodontology's most important disease in order to promote ever better approaches to its diagnosis, prevention, and therapy'

The update of this textbook comes 12 years after the second edition. Previously co-edited by the late Thomas R. Pitt Ford, the new edition builds on his legacy. The chapters have been rearranged and rewritten by, in the main, different authors with a completely new chapter on the 'Biological basis for endodontic repair and regeneration'. The Foreword highlights the growth in the output of publications on endodontics with a staggering 14,685 being counted between 2008 and 2017 compared to a mere 6,525 between 1998 and 2007. Dag Ørstavik argues from this the necessity of a textbook to compress this knowledge for the novice and provide a 'backbone of knowledge and insights. The publication is accompanied on its companion website by a number of downloadable figures. This book can also be read as part of the library's ebook collection - www.bda.org/ebooks.

\section{Conservative Dentists group launched}

Conservative Dentists (CD) was recently launched at a sold-out event entitled 'Prevention is better than Cure', at the Palace of Westminster. There will be little disagreement that there is a lack of representation for dentists within all the political parties and Conservative Dentists was set up to combat this. The aims of the organisation are to form a bridge between the dental and political worlds thereby improving dialogue between the two and helping to influence policy.

The audience was diverse and varied, with representation from the British Dental Association (BDA), British Society of Paediatric Dentistry (BSPD), Public Health England and others and members were given the opportunity to question a panel which included the Minister for Dentistry Jo Churchill, the Chief Dental Officer (CDO) Sara Hurley, and MPs in the room, and raise the issues they were concerned about within dentistry. The discussion quickly jumped to water fluoridation and Jo Churchill, Sara Hurley and Sir Paul Beresford MP (the only practising dentist who is also an MP) made a plea for dentists to back fluoridation with the room being in consensus. Sir Paul recently made a parliamentary intervention stating that community water fluoridation is a well discussed public health tool and that 'at the moment there's an atmosphere that we can push through water fluoridation in this government. We have a unique opportunity, let's grab it'.

Jo Churchill said: 'Water fluoridation is the quickest and easiest way to improve our oral health, but we would really like [the dental profession's] help; we need dentists to talk to their patients about the benefits of water fluoridation. We need to move the dial, so the next generation can benefit from great oral health.'

To take the momentum within the room forward attendees were asked to give feedback on the state of dentistry in the UK and what policy ideas should be implemented to improve the provision of dental care. This will be collated and a report presented to the $\mathrm{CDO}$ and the Minister for Dentistry with future events planned accordingly. If you would like to get involved or join Conservative Dentists please contact: sejalbhansali@ymail.com.

This report was written by Sejal Bhansali, Chair and Founder of CD.

\section{New Masters of Surgery in Aesthetics launched}

University College London (UCL) will be the first ever global academic institution to offer a comprehensive Masters of Surgery (MS) in Aesthetics.

September 2021 will see the introduction of the programme at UCL's Division of Surgery \& Interventional Science. The new programme will include two courses: Master of MS in 1) Aesthetic Surgery and 2) Minimally-Invasive Aesthetics.

The programme will be led by Professor Afshin Mosahebi and include blended learning with 12 days of face to face teaching at UCL's world-leading faculty in aesthetic surgery and non-surgical aesthetics at the Royal Free Hospital - for practical skills-based sessions as well as remote on-line learning

Currently there is an absence of any standards or accredited training for non-surgical cosmetic procedures. The current regulatory framework places no restrictions on who may perform non-surgical cosmetic procedures. No qualifications are required to carry out these procedures and, in the absence of accredited training courses, anyone can set up a training course purporting to offer a qualification. As a result, a number of self-accredited training organisations have sprung up.

Aesthetic surgery and regenerative medicine have emerged as key growth areas within healthcare delivery across the world. An increasing number of healthcare professionals now offer treatments designed to refresh facial and overall appearance by surgery or minimally invasive procedures (immobilising facial muscles or providing dermal fillers).

As this sector of medicine is outside of the NHS in the UK, its governance and standards of care have been the focus of much debate over recent years. In an attempt to combat this, there is a growing push to fully legitimise this sector of medicine with the British Association of Aesthetic Surgeons (BAAPS) advising patients to ensure that their surgeon or practitioner is fully licensed and accredited and they are in full support of the programme.

BAAPS is supportive of the UCL Masters endeavour which helps to improve the standards of training in the aesthetic field. BAAPS research strategy will help to form the research element of the Masters and direct the future improvement and safety of aesthetic practice. 